\title{
Intercontinental genetic divergence of Castanea species in eastern Asia and eastern North America
}

\author{
F Dane ${ }^{1}, \mathrm{P} \mathrm{Lang}^{1}, \mathrm{H}$ Huang ${ }^{2}$ and $\mathrm{Y} \mathrm{Fu}{ }^{1,3}$ \\ ${ }^{1}$ Department of Horticulture, Auburn University, AL, USA; ${ }^{2}$ Wuhan Institute of Botany, The Chinese Academy of Sciences, Hubei, \\ People's Republic of China
}

\begin{abstract}
Castanea is one of the many plant genera with a disjunct distribution pattern between eastern Asia and eastern North America. Five species from three sections of the genus were investigated to examine genetic divergence between eastern Asian and eastern North American species. A total of 62 native populations were sampled for allelic variation at isozyme loci. The Chinese chestnut $C$. mollissima had the highest genetic variability, while the American $C$. dentata had the lowest genetic variability. The highest intracontinental genetic identities were observed between the Allegheny and Ozark chinkapins (0.931) and between C. mollissima and C. seguinii (0.870), while lower identities were detected between the American $C$. pumila and $C$. dentata $(0.720-$
\end{abstract}

0.729). In intercontinental comparisons, genetic identities of $0.505,0.495$ and 0.507 were observed between the American chestnut and the Chinese C. mollissima, $C$. seguinii and $C$. henryi, respectively, whereas the Ozark chinkapin $C$. pumila var. ozarkensis had lower identities of 0.469 , and 0.435 with $C$. mollissima and $C$. seguinii, respectively, but a slightly higher identity of 0.520 with $C$. henryi, the Chinese chinkapin. Divergence times were estimated at 10-13 million years before present between $C$. dentata and $C$. mollissima, and $C$. pumila var. ozarkensis and $C$. henryi.

Heredity (2003) 91, 314-321. doi:10.1038/sj.hdy.6800300

Keywords: Castanea; genetic divergence; allozyme; genetic variability; disjunct species divergence time

\section{Introduction}

The study of the floristic similarity among temperate forests of North America, Europe and Asia dates back to the 18th century, when Halenius, a student of Linnaeus, first described the phenomenon. Scientists soon recognized that this disjunction spanned all temperate forests of the northern Hemisphere (Boufford and Spongberg, 1983). It is now recognized that the complex history of tectonics, climate fluctuations, repeated emergence and submergence of land bridges, multiple migrations and other factors have led to the current distributions of northern temperate forests, which were contiguous during the Miocene (15 million years before present) when the northern continents were in contact (Wen, 1999; Guo and Ricklefs, 2000).

Castanea Miller is one of at least 65 plant genera with a disjunct distribution pattern between eastern Asia and eastern North America (Wen, 1999). The genus comprises three sections and seven species (Johnson, 1988). Section Castanea, characterized by the presence of three nuts per cupule, contains five species of varying economic importance as nut tree crops, and is widely distributed over the temperate zone of the Northern Hemisphere, in eastern and western Asia, eastern North America and southern Europe. Three species, Chinese chestnut

Correspondence: F Dane, Department of Horticulture, Auburn University, AL, USA. E-mail: fdane@acesag.auburn.edu

${ }^{3}$ Current address: Department of Entomology, Texas A \& M University, College Station, TX 77843-2475, USA

Received 2 November 2001; accepted 25 February 2003
(C. mollissima B1.), Seguin chestnut (C. seguinii Dode.) and Japanese chestnut (C. crenata Sieb. \& Zucc.) occur in eastern Asia. Chinese chestnut has a natural range over much of mainland China except western deserts and plateaus, and Seguin chestnut occurs sympatrically with Chinese chestnut over central and southwest China (Lang and Huang, 1999). Japanese chestnut (C. crenata Sieb. \& Zucc.) is found on the Japanese islands and Korean peninsula (Jaynes, 1975). American chestnut (Castanea dentata (Marsh.) Borkh.) is native to eastern North America, growing from southern Maine south to Georgia, Alabama and Mississippi, and west to southern Ontario and Michigan (Saucier, 1973). European chestnut (C. sativa Mill.) is native to western Asia and southern Europe (Villani et al, 1994). Section Balanocastanon, characterized by one nut per cupule, has a single species C. pumila Mill., commonly called American chinkapin. This species comprises two varieties: var. pumila, the Allegheny chinkapin, with a wide distribution from southern New Jersey and Pennsylvania, west to Indiana and Missouri, and south to Florida and Texas, and var. ozarkensis (Ashe) Tucker, the Ozark chinkapin, with limited and fragmented distribution in the Ozark Mountains of eastern Oklahoma, southwest Missouri, and north-central Arkansas (Johnson, 1988). Section Hypocastanon contains only one species, C. henryi (Skan) Rehder \& Wilson, which is found in a restricted area in southeast China, and is sometimes called Chinese chinkapin since it is characterized by a single nut per cupule (Lang and Huang, 1999). The geographical distribution of Castanea species in China and the United States has a similar 
pattern in that geographically restricted species (C. sequinii and C. henryi in China, and C. pumila in the US) overlap widespread species (C. mollissima in China and $C$. dentata in the US).

Adequate data on basic biology, genetics and interspecific crossing compatibility, as well as fossil records of Castanea species are available largely because of their economic importance as nut tree crops. Relatively few subtle characters (nut numbers per cupule, cupule valves, leaf blade and vestiture types) are useful for distinguishing the species (Graves, 1949; Johnson, 1988). All species are diploid $(2 n=2 x=24)$, wind pollinated and hybridize freely, although some interspecific $F_{1}$ 's usually suffer from low seed germination and male sterility (Jaynes, 1975).

The historical event of chestnut blight (a fungal disease caused by Cryphonectria parasitica (Murrill) Barr), which devastated Castanea species in North America since the beginning of the 20th century and in Europe since 1930, remains an unsolved problem for plant breeders and horticulturists worldwide. Blight resistance among the species differs: the American and the European species are susceptible, while the Asian species are blight resistant (Graves, 1950; Huang et al, 1996). The American chestnut is most susceptible (Graves, 1950) and the narrow genetic diversity of the American chestnut as compared to congeneric species and closely related Quercus species may have contributed to its demise (Huang et al, 1998). It was hypothesized that the Asian (progenitor) species evolved in the presence of the disease epidemic and retained disease resistance, while the American chestnut lost its resistance as it evolved in the disease-free environment on the North American continent (Jaynes, 1975).

Fossils of Castanea have been found throughout the Tertiary in the Northern Hemisphere: Japan (Oligocene); North Korea (Miocene); far eastern Russia (late Eocene, Miocene and early Miocene), Siberia and western Siberia (early Miocene); eastern Russia (late Oligocene) and central Russia (late Eocene, Oligocene, late Miocene and middle Miocene); western Asia (Oligocene); eastern Europe (early Eocene and late Eocene, Oligocene, late Oligocene and early Oligocene, Miocene, middle Miocene and late Miocene, Pliocene and late Pliocene); central Europe (late Eocene, Oligocene, late Oligocene and early Oligocene, late Miocene and middle Miocene, Pliocene); southern Europe (Pliocene); northwestern Europe (Paleocene and Pliocene) (International Organization of Palaeobotany, 1997); northeastern, eastern and southwestern China (late Eocene, Miocene and Pliocene) (International Organization of Palaeobotany, 1997; Zhou, 1999); and North America (Eocene and Miocene)(Crepet and Daghlian, 1980; Zhou, 1999). Although accuracy of the fossil record needs to be considered, Castanea, like other genera in Fagaceae, most likely appeared as early as the Paleocene and reached the widest distribution during Miocene (Zhou, 1999). Little is known about the evolutionary and genetic relationship of these morphologically similar but intercontinentally isolated species of Castanea.

The evolution of eastern Asia and eastern North American disjunct distributions of flowering plants has recently been reviewed by Wen (1999). While phylogeographic studies did confirm affinities between many of the disjunct taxa, patterns of diversification of species on one or both continents were found and disjunct species pairs were rarely each other's closest relatives (Wen, 1999; Guo and Ricklefs, 2000). In many woody plant genera, current estimates of divergence time using molecular and fossil data suggest that the disjunct patterns were established in the range of $2-25$ mybp during the Miocene (Wen, 1999). Information on Fagaceae has so far been limited or inconclusive (Stanford, 1998). Chloroplast (cp) DNA studies on European chestnut (C. sativa) showed low levels of differentiation among populations, which has been related to the impact of human colonization (Fineschi et al, 2000). The purpose of the present investigation was to: (1) determine evolutionary relationships between eastern Asian and North American Castanea species using allozyme analysis of a large number of wild populations and (2) compare divergence in this genus with that of other woody angiosperms with eastern Asia-eastern North American disjunct taxa.

\section{Materials and methods}

\section{Plant material}

In North America, 12 populations of C. dentata were sampled across the native range along Appalachia from Alabama to central New York, during 1994 and 1995; nine populations of $C$. pumila var. ozarkensis were sampled in the centre of its native habitat of the Ozark mountains in Arkansas, during 1996-1997; 11 populations of C. pumila var. pumila were sampled in the southeastern states during 1998-2000 (Table 1, Figure 1a).

In People's Republic of China, 21 wild populations of C. mollissima were sampled in 1997 from northern, central and southwestern China in the native range of the species, representing the entire, diversity of the species; six populations of $C$. seguinii and three populations of C. henryi were sampled in 1997 in central China, the centres of the species' range, except one population of C. seguinii was sampled from Guangxi, southern China (Table 1, Figure 1b).

Samples of most populations were collected as seeds from which cotyledonary (diploid) tissues yielded the highest quantity and quality of isozymes, and produced the most consistent and reproducible banding patterns. For $C$. dentata populations and a few populations of other species from which seeds could not be obtained, 1-yearold dormant twigs with mature buds were taken from trees, kept in zip-lock bags at $4^{\circ} \mathrm{C}$ until electrophoresis was conducted. Enzymes extracted from cotyledonary tissues of seeds or mature buds of one-year-old twigs had been tested earlier for identity and reliability (Huang et al, 1994a).

\section{Allozyme analysis}

Procedures for allozyme electrophoresis, genetic analysis and allele designation of the loci have been described in detail (Huang et al, 1994a,b; Dane et al, 1999; Dane and Huang, 2002). The isoelectric focusing polyacrylamide slab gel system ( $\mathrm{pH} 4-9)$ or precast agarose gels $(\mathrm{pH} 4-6)$ were used. Gels were assayed for acid phosphatase (ACP; EC 3.2.3.2), alcohol dehydrogenase (ADH; EC 1.1.1.1.), aconitase (AK; EC 4.2.1.3), diaphorase (DIA; EC 1.8.1.41), esterase (EST; EC 3.1.1), formate dehydrogenase (FDH; EC 1.2.1.2), glutamate dehydrogenase (GDH; EC 
Table 1 Populations of Castanea sampled for allozyme divergence between eastern Asia and eastern North America

\begin{tabular}{|c|c|c|c|c|c|}
\hline Species & Population & Size & No loci & Code & Location \\
\hline \multirow[t]{12}{*}{ C. dentata } & Am-94-1 & 20 & 18 & $\mathrm{AL}$ & Macon Co, AL, USA \\
\hline & Am-94-2 & 21 & 18 & GA & Black Rock Mt. State Park, GA, USA \\
\hline & Am-94-3 & 21 & 18 & NC1 & Nantahala National Forest, NC, USA \\
\hline & Am-94-4 & 29 & 18 & NC2 & Thomas Ridges, Great Smoky Mt, NC, USA \\
\hline & Am-94-5 & 17 & 18 & VA1 & Glade, Smyth Co, VA, USA \\
\hline & Am-94-6 & 28 & 18 & VA2 & Plummer, Smyth Co, VA, USA \\
\hline & Am-94-7 & 25 & 18 & PA1 & York Co, PA, USA \\
\hline & Am-94-8 & 21 & 18 & PA2 & Southern PA, USA \\
\hline & Am-94-9 & 31 & 18 & $\mathrm{OH}$ & Carroll $\mathrm{Co}, \mathrm{OH}, \mathrm{USA}$ \\
\hline & Am-94-10 & 20 & 18 & MI & Southeastern MI, USA \\
\hline & Am-94-11 & 16 & 18 & NY & Troy, NY, USA \\
\hline & Am-94-12 & 11 & 18 & $\mathrm{CT}$ & Essex, CT, USA \\
\hline \multirow[t]{9}{*}{ C. pumila var. ozarkensis } & Oz-97-1 & 15 & 14 & OZ1 & Sylamore Ranger District, AR, USA \\
\hline & Oz-97-2 & 46 & 14 & OZ2 & Sylamore Ranger District, AR, USA \\
\hline & Oz-97-3 & 29 & 14 & OZ3 & Sylamore Ranger District, AR, USA \\
\hline & Oz-97-4 & 38 & 14 & OZ4 & Sylamore Ranger District, AR, USA \\
\hline & Oz-98-1 & 36 & 14 & OZ5 & Sylamore Ranger District, AR, USA \\
\hline & Oz-98-2 & 35 & 14 & OZ6 & Sylamore Ranger District, AR, USA \\
\hline & Oz-98-3 & 7 & 14 & OZ7 & Sylamore Ranger District, AR, USA \\
\hline & Oz-98-4 & 8 & 14 & OZ8 & Sylamore Ranger District, AR, USA \\
\hline & Oz-98-5 & 27 & 14 & OZ9 & Newton Co, AR, USA \\
\hline \multirow[t]{11}{*}{ C. pumila var. pumila } & Pu-98-1 & 96 & 15 & AL-U & Uchee, AL, USA \\
\hline & $\mathrm{Pu}-98-2$ & 36 & 15 & FL-E & Eglin Air Force Base, FL, USA \\
\hline & $\mathrm{Pu}-98-3$ & 36 & 15 & FL-G & Eglin Air Force Base, FL, USA \\
\hline & $\mathrm{Pu}-98-4$ & 17 & 15 & FL-I & Eglin Air Force Base, FL, USA \\
\hline & Pu-98-5 & 82 & 15 & FL-L & Eglin Air Force Base, FL, USA \\
\hline & $\mathrm{Pu}-98-6$ & 70 & 15 & OH-p & Carroll Co, OH, USA \\
\hline & $\mathrm{Pu}-98-7$ & 206 & 15 & VA & Smyth Co, VA, USA \\
\hline & Pu-98-8 & 126 & 15 & VB & Smyth Co, VA, USA \\
\hline & Pu-99-1 & 21 & 15 & MS & Leake Co, MS, USA \\
\hline & $\mathrm{Pu}-99-2$ & 65 & 15 & FL-B & Eglin Air Force Base, FL, USA \\
\hline & $\mathrm{Pu}-99-3$ & 60 & 15 & FL-D & Eglin Air Force Base, FL, USA \\
\hline \multirow[t]{21}{*}{ C. mollissima } & Ch-97-1 & 24 & 20 & $\mathrm{BJ}-\mathrm{c}$ & Changping Co, Beijing, China \\
\hline & Ch-97-2 & 24 & 20 & BJ-h & Huairou Co, Beijing, China \\
\hline & Ch-97-3 & 24 & 20 & HB-f & Fangxian Co, Hubei, China \\
\hline & Ch-97-4 & 24 & 20 & SNJ & Shengnongjia Mt, Hubei, China \\
\hline & Ch-97-5 & 24 & 20 & HB-y & Yichang Co, Hubei, China \\
\hline & Ch-97-6 & 24 & 20 & HB-Z & Zigui Co, Hubei, China \\
\hline & Ch-97-7 & 24 & 20 & HB-w1 & Wufeng Co, Hubei, China \\
\hline & Ch-97-8 & 24 & 20 & HB-w2 & Wufeng Co, Hubei, China \\
\hline & Ch-97-9 & 24 & 20 & HB-1 & Luotian Co, Hubei, China \\
\hline & Ch-97-10 & 24 & 20 & HB-t & Tongcheng Co, Hubei, China \\
\hline & Ch-97-11 & 24 & 20 & HN-y & Yongshun $\mathrm{Co}$, Hunan, China \\
\hline & Ch-97-12 & 24 & 20 & GZ-b & Bijie Co, Guizhou, China \\
\hline & Ch-97-13 & 24 & 20 & GZ-y & Yuping Co, Guizhou, China \\
\hline & Ch-97-14 & 24 & 20 & GX-n & Nandan Co, Guangxi, China \\
\hline & Ch-97-15 & 24 & 20 & $G X-x$ & Xingan Co, Guangxi, China \\
\hline & Ch-97-16 & 24 & 20 & GX-z & Ziyuan $\mathrm{Co}$, Guangxi, China \\
\hline & Ch-97-17 & 24 & 20 & GX-d & Donglan Co, Guangxi, China \\
\hline & Ch-97-18 & 24 & 20 & YU-11 & Luquan Co, Yunnan, China \\
\hline & Ch-97-19 & 20 & 20 & YU-12 & Luquan Co, Yunnan, China \\
\hline & Ch-97-20 & 25 & 20 & YU-y & Yiliang Co, Yunnan, China \\
\hline & Ch-97-21 & 24 & 20 & YU-m & Malipo Co, Yunnan, China \\
\hline \multirow[t]{6}{*}{ C. seguinii } & Ch-97-22 & 24 & 20 & HB-ys & Yichang Co, Hubei, China \\
\hline & Ch-97-23 & 24 & 20 & HB-zs & Zigui Co, Hubei, China \\
\hline & Ch-97-24 & 24 & 20 & HB-t1 & Tongcheng Co, Hubei, China \\
\hline & Ch-97-25 & 24 & 20 & HB-t2 & Tongcheng Co, Hubei, China \\
\hline & Ch-97-26 & 24 & 20 & HB-ls & Luotian Co, Hubei, China \\
\hline & Ch-97-27 & 22 & 20 & GX-xs & Xingan Co, Guangxi, China \\
\hline \multirow[t]{3}{*}{ C. henryi } & Ch-97-28 & 21 & 20 & HB-yh & Yichang Co, Hubei, China \\
\hline & Ch-97-29 & 24 & 20 & HB-fh & Fangxian Co, Hubei, China \\
\hline & Ch-97-30 & 24 & 20 & GX-zh & Ziyuan Co, Guangxi, China \\
\hline
\end{tabular}


a
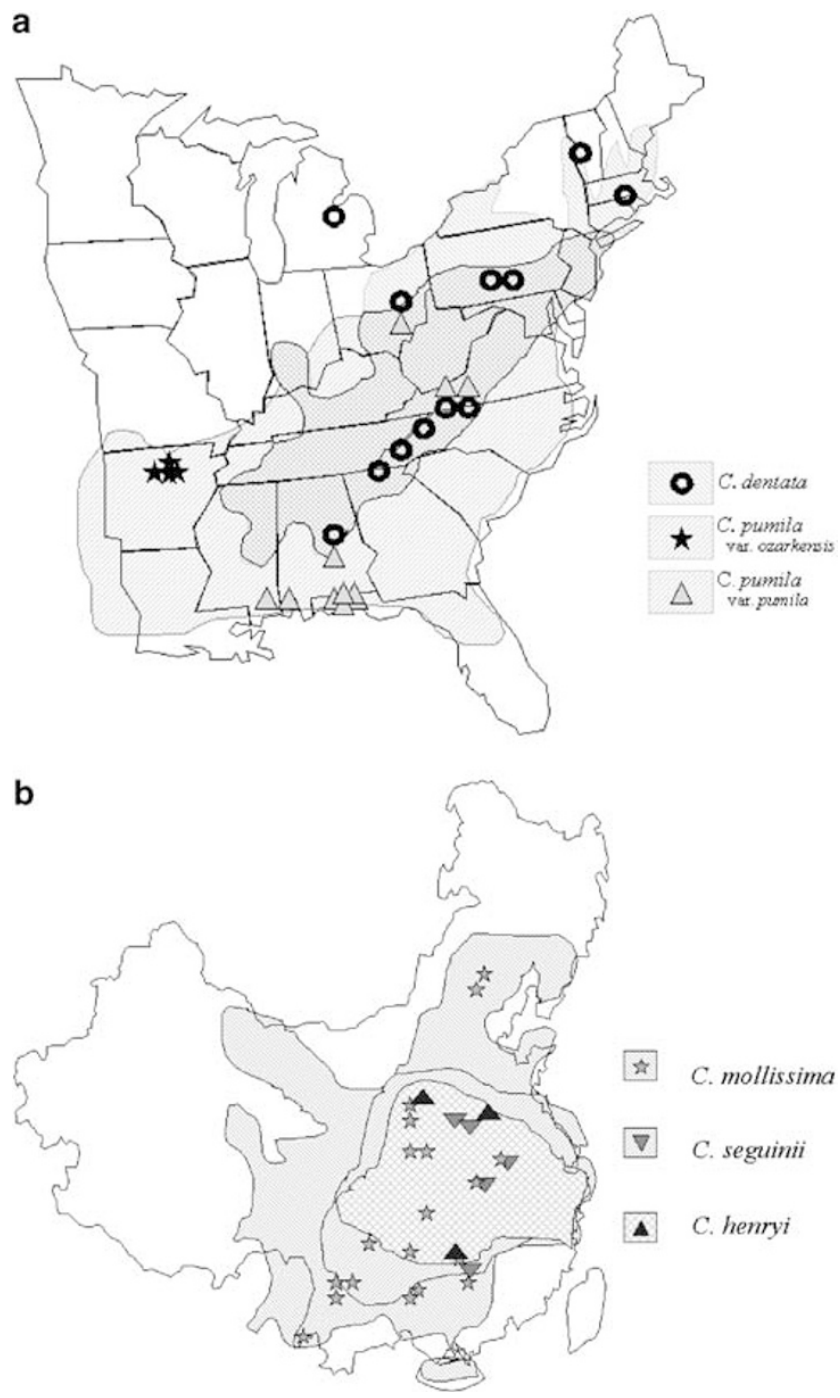

Figure 1 (a) Location of natural populations of Castanea dentata, C. pumila var. ozarkensis and C. pumila var. pumila collected in North America. (b) Location of natural populations of C. mollissima, C. seguinii and C. henryi collected in People's Republic of China.
Intercontinental genetic divergence of Castanea species

F Dane et al

1.4.1.2), isocitrate dehydrogenase (IDH; EC 1.1.1.41), malate dehydrogenase (MDH; EC 1.1.1.37), malic enzyme (ME; EC 1.1.1.40), phosphoglucoisomerase (PGI; EC 5.3.1.3), phosphogluconate dehydrogenase (PGD; EC 1.1.1.44), phosphoglucomutase (PGM; EC 5.4.2.2), peroxidase (PRX; EC 1.11.1.7), shikimate dehydrogenase (SKD; EC 1.1.1.25), superoxide dismutase (SOD; EC 1.12.1.1) and triosephosphate isomerase (TPI; EC 5.3.1.1). The following loci were scored when possible: Acp-1, Acp-2, Acp-3, Adh-1, Ak-2, Dia-1, Dia-2, Dia-3, Dia-4, Dia-6, Est-1, Est-2, Est-4, Est-5, Fdh, Gdh, Idh, Mdh-2, Me, Pgi-1, Pgi-2, PgD, Pgm, Prx-1, Prx-2, Prx-3, Prx-4, Skd-1, Skd-2, Skd-3, Skd-4, Sod-1 and Tpi (Table 1).

\section{Data analysis}

Allele frequencies for isozyme loci were estimated (Nei, 1987), and a set of measures of intra-and interpopulation genetic statistics were generated using a computer program developed by BIOSYS-1 (Swofford and Selander, 1981) and NTSYS Version 2.1 (Rohlf, 2000). Nei's (1978) genetic distance and identity were calculated for all pairwise combinations of populations using the maximum number of shared loci. A dendrogram was constructed based on the matrix of Nei's distance using unweighted pair-group mean analysis (UPGMA). Divergence times were estimated using the rate of 1 unit of Nei's genetic distance per 15-20 mybp (Sarich, 1977).

\section{Results}

Castanea species in eastern Asian and eastern North America showed continent-specific loci, although the five species shared most loci and most high-frequency alleles. While $S k d-1$ and $S k d-2$ were observed in the American species, $S k d-3$ and $S k d-4$ were detected in the Chinese species and interspecific hybrids between $C$. mollissima and C. dentata showed all four Skd loci. Pgi-2b and Pgi-2d alleles were only detected in C. mollissima, with $P g i-2 b$ unique to the Shennongjia population in central China. $C$. henryi could be distinguished from $C$. mollissima and C. seguinii by the absence of Me-1c. Dia-6b and $c$ alleles were only detected in C. pumila var. ozarkensis.

Table 2 Allozyme variability measures averaged for all populations of each species in eastern Asia and eastern North America Castanea species

\begin{tabular}{|c|c|c|c|c|c|c|c|c|}
\hline \multirow[t]{2}{*}{ Species } & \multicolumn{8}{|c|}{ Genetic diversity parameters } \\
\hline & $P$ & $A$ & $H_{o b s}$ & $H_{\exp }$ & $H_{T}$ & $G_{S T}$ & $F$ & $I$ \\
\hline C. mollissima $a^{\mathrm{a}}$ & 90 & 2.2 & 0.284 & $0.311(0.253-0.341)$ & 0.321 & 0.075 & 0.087 & $0.963(0.896-0.999)$ \\
\hline C. seguiniti & 82.4 & 2.1 & 0.192 & $0.186(0.130-0.188)$ & 0.187 & 0.109 & -0.032 & $0.980(0.947-0.999)$ \\
\hline C. henryia & 76.5 & 2.1 & 0.218 & $0.261(0.192-0.247)$ & 0.282 & 0.221 & 0.165 & $0.935(0.929-0.946)$ \\
\hline C. dentata ${ }^{\mathrm{b}}$ & 60 & 1.7 & 0.184 & $0.167(0.096-0.196)$ & 0.214 & 0.087 & -0.091 & $0.972(0.902-0.999)$ \\
\hline C. pumila var. pumilac & 72.7 & 1.9 & 0.206 & $0.296(0.115-0.295)$ & 0.296 & 0.137 & 0.187 & $0.980(0.962-0.997)$ \\
\hline C. pumila var. ozarkensis ${ }^{\mathrm{d}}$ & 63.3 & 1.8 & 0.272 & $0.228(0.191-0.265)$ & 0.341 & 0.147 & -0.117 & $0.977(0.934-1.000)$ \\
\hline
\end{tabular}

$\mathrm{P}=$ percent polymorphic loci; $\mathrm{A}=$ number of alleles per locus; $H_{\mathrm{obs}}=$ observed heterozygosity; $H_{\mathrm{exp}}=$ Hardy-Weinberg expected heterozygosity; $H_{\mathrm{T}}=$ total genetic diversity; $G_{\mathrm{ST}}=$ relative magnitude of genetic differentiation among populations; $F=$ fixation index; $I=$ Identity.

a Lang and Huang (1999)

bHuang et al (1998)

${ }^{\mathrm{c}} \mathrm{Fu}(2001)$

dDane et al (1999). 
The mean genetic variability for each species is given in Table 2. C. mollissima showed the highest population genetic variability, while $C$. dentata had the lowest genetic variability. The expected genotype frequencies at most loci in most populations of these two widespread species in eastern Asia and eastern North America, conformed to Hardy-Weinberg expectation $(P<0.05)$, with marginally positive fixation indices in $C$. mollissima (0.087) and negative fixation indices in $C$. dentata $(-0.091)$. However, significant heterozygosity deficiencies $(P<0.05)$ were found in the narrowly distributed $C$. henryi $(F=0.165)$, and heterozygosity excess was detected in the restricted C. pumila var. ozarkensis $(F=-0.117)$. High genetic variability was observed in $C$. henryi and C. pumila var. ozarkensis, even though C. pumila var. ozarkensis populations were sampled from a limited area in Arkansas and geographically isolated from C. pumila var. pumila populations (Table 2).

Nei's (1978) genetic identity and distance were calculated for all pairwise population comparisons and the results of averaged values using the maximum number of loci shared by the different species are presented in Table 3. In intracontinental species comparisons, high genetic identities were observed among the three Chinese species, ranging from 0.835 for $C$. mollissima and $C$. henryi to 0.870 between $C$. mollissima and $C$. seguinii. Among the American species, the highest identity (0.930) was found between two varieties of the American chinkapin, while the lowest (0.720) was between $C$. dentata and C. pumila var. pumila. In intercontinental comparisons, the North American $C$. dentata had genetic identities of $0.505,0.495$ and 0.507 with the Chinese C. mollissima, C. seguinii and C. henryi, respectively. The Ozark chinkapin, C. pumila var. ozarkensis had lower identities of 0.469 , and 0.435 with C. mollissima, and C. seguinii, respectively, but higher identity of 0.520 with $C$. henryi (Table 3). These intracontinental and intercontinental relationships were reflected on the UPGMA dendrogram (Figure 2).

\section{Discussion}

The genetic variability found in C. mollissima is the highest among the Castanea species examined here, and higher than that previously reported for European chestnut (C. sativa, $H_{\exp }=0.24-0.27$ ) (Pigliucci et al, 1991; Villani et al, 1994). High levels of genetic variability were detected in C. mollissima populations distributed in the Changjian river area, particularly in Shennongjia. This region is well known for its variable topography, different climatic ranges influenced by mountain ranges. Warm climates during the last glaciation period have provided an ideal refuge area for many ancient endemic plant and animal species (such as Dawn redwood, Metasequoia glyptostroboides, and Panda, Ailuropoda melanoleucus ). As a consequence central and southwestern populations maintained higher levels of genetic variability than northern populations at the margin of the species range. Many plant species were forced southward during the glacial maximum to refugia and migrated northward after the glaciers' retreat (Zheng, 1983).

The low genetic variability detected in C. dentata, which is as widespread as $C$. mollissima, might be the consequence or cause of the rapid decline of the species 


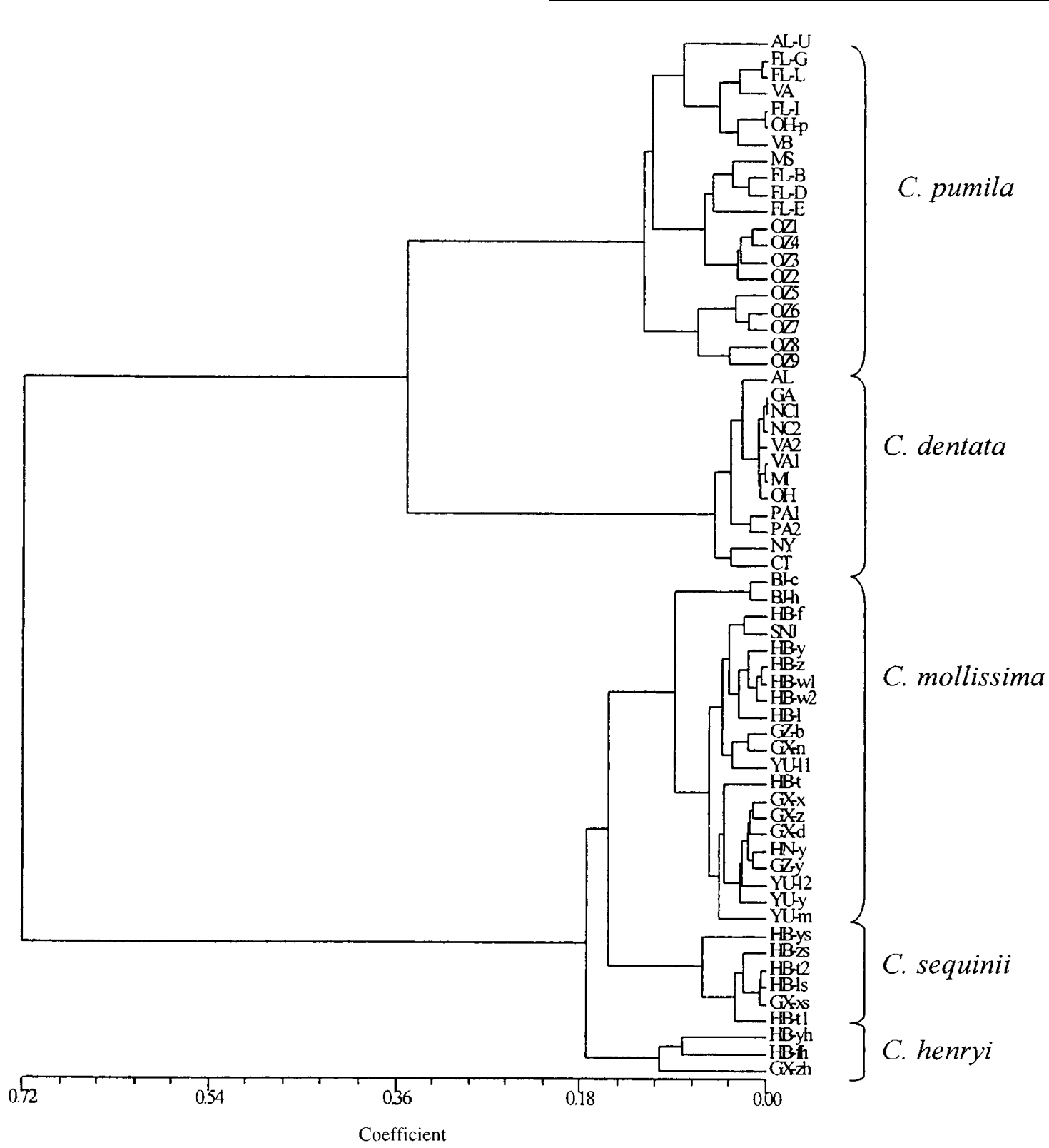


nuts per cupule in C. henryi and development of precocious growth habit in $C$. seguinii. Reduction in the number of nuts per cupule might have evolved independently on both continents. Burs with two to three nuts instead of one have been observed at low frequency on C. pumila trees. Lack of significant morphological changes in a species over a long period of time or morphological stasis has been observed in eastern Asian and eastern North American disjunct tree genera such as Liriodendron (Parks and Wendel, 1990), Liquidambar (Hoey and Parks, 1991), Magnolia (Qui et al, 1995), Gleditsia and several other taxa (Wen, 1999). Evolutionary constraints and stabilizing selection are proposed to be major mechanisms for morphological stasis (Wen, 1999).

Estimation of divergence time using Nei's genetic distance translates to similar divergence time of 10 13 mybp between $C$. dentata and C. mollissima; C. pumila var. pumila and C. mollissima, C. dentata and C. henryi, C. pumila var. ozarkensis and C. henryi. Even though these estimates are in accordance with divergence times in several woody genera (between 2-25 mybp) with disjunct patterns using molecular and fossil data (Wen, 1999), the problem with the electrophoretic protein clock is that reliable independent estimates of species or population divergence are largely lacking (Nei, 1987).

In the case of the genus Castanea, it is reasonable to assume that extinct Castanea species existed from Paleocene to Pliocene in a much wider distribution of the Northern Hemisphere, and that species exchange remained via the Bering land bridge during the late Miocene to maybe early Pliocene, which is supported by fossil records (International Organization of Palaeobotany, 1997). Sargent (1896) mentioned the existence of Castanea in northern Greenland, and in Alaska and leaf impressions in Miocene rocks of Oregon, and Colorado. The ancient western American population was probably destroyed by the geological uplift of the Rocky Mountains and concomitant climate deterioration. Contemporary patterns of diversity suggest that the effects of climate changes in the late Tertiary were less severe in eastern Asia and promoted diversification, but were more severe in North America and may have caused extinction (Guo and Ricklefs, 2000). Stanford's (1998) cpDNA sequencing study of the matK region indicated two major Castanea clades with the three Chinese species supported as a single clade, whose sister group contained the four other species of the genus with the Japanese species (C. crenata) most closely related to $C$. dentata. C. pumila appeared most closely related to the European chestnut (C. sativa), suggesting multiple migrations.

The quaternary history of $C$. sativa has been well documented, indicating that the species retreated back to western Asia and survived as a relict in a few locations of south-eastern Europe and Turkey (Huntley and Birks, 1983; Villani et al, 1994; Fineschi et al, 2000). It is the late expansion, which occurred after the end of Pleistocene about 5000 year ago, that formed the present distribution patterns in eastern Asia-Europe. In eastern North America, the American species were driven southward to refugia in the Gulf Coastal region and Florida during the Wisconsin glacial maximum 18000-20000 years ago and migrated northward along Appalachia after the glacier's retreat (Davis, 1983; Huang et al, 1998).
The pattern of eastern Asian and eastern North American disjunct taxa in Castanea could be a combination of results of geographical and evolutionary historical events involved in both the early and later Tertiary, via both Bering and North Atlantic land bridges. Fossils, geological, molecular and phylogenetic evidence in other taxa similarly suggests complex origins of disjunct taxa between eastern Asia and eastern North America. The pattern is the product of vicariance, dispersal, extinction and speciation (Wen, 1999). Collaborations among phylogenetists, paleobotanists and geologists are needed to gain better insights into the origin and evolution of these complicated eastern Asian-eastern North American disjunct patterns.

\section{Acknowledgements}

The authors thank USDA-ARS and National Science Foundation of China (NSFC) for partial support of this work. We also thank Joe Norton, Bill Carey, Dan James, Fred Hebard, Ann Leffel, John Logan, Karen Tinkle, Ralph Odegard, George Johnson, Jan Self, Paul Sisco, Bill Piercy, Richard McWhite, Greg Miller, Bill Nash, Phillip Gordon, John Gordon, Scott Schlarbaum, Bill McDonald, Herbert Darling, Frank Munzer, William Raoul, Anthony Lampros and John Herrington for their help with field sampling, and the technical assistance of Rasima Bakhtiyarova.

\section{References}

Boufford DE, Spongberg SA (1983). Eastern Asia-North American phytogeographical relationships-a history from the time of Linnaeus to the twentieth century. Ann Missouri Bot Gard 70: 425-439.

Crepet WL, Daghlian CP (1980). Castaneoid inflorescences from the middle Eocene of Tennessee and diagnostic value of pollen (at the subfamily level) in the Fagaceae. Am J Bot 67: 739-757.

Dane F, Hawkins LK, Huang H (1999). Genetic variation and population structure of Castanea pumila var. ozarkensis. J Am Soc Hort Sci 124: 666-670.

Dane F, Huang H (2002). Short note: variability and inheritance of diaphorases in American and Chinese Castanea species. Silvae Genet 51: 128-130.

Davis MB (1983). Quaternary history of deciduous forests of eastern North American and Europe. Ann Missouri Bot Gard 70: 550-563.

Fineschi S, Taurchini D, Villani F, Vendramin GG (2000). Chloroplast DNA polymorphism reveals little geographical structure in Castanea sativa Mill. (Fagaceae) throughout southern European countries. Mol Ecol 9: 1495-1503.

Fu Y (2001). Analysis of Genetic Variation in Endangered Allegheny Chinkapin (Castanea pumila var. pumila) Populations using Allozyme and RAPD Markers. MSc Thesis, Auburn University, AL.

Graves AH (1949). Key to chestnut species, with notes on some hybrids. Annu Rep Northern Nut Growers Assoc, 40: 95-107.

Graves AH (1950). Relative blight resistance in species and hybrids of Castanea. Phytopathology 49: 1125-1131.

Guo Q, Ricklefs RE (2000). Species richness in plant genera disjunct between temperate eastern Asia and North America. Biol J Linnean Soc 134: 401-423.

Hoey MT, Parks CR (1991). Isozyme divergence between eastern Asia, North America, and Turkish species of Liquidambar (Hamamelidaceae). Am J Bot 78: 938-947.

Huang H, Dane F, Norton JD (1994a). Genetic analysis of 11 polymorphic isozyme loci in chestnut species and character- 
ization of chestnut cultivars by multi-locus allozyme genotypes. J Amer Soc Hort Sci 119: 840-849.

Huang H, Dane F, Norton JD (1994b). Allozyme diversity in Chinese, Seguin and American chestnut (Castanea spp.). Theor Appl Gen 88: 981-985.

Huang H, Carey WA, Dane F, Norton JD (1996). Evaluation of Chinese chestnut cultivars for resistance to Cryphonectria parasitica. Plant Dis 80: 45-47.

Huang H, Dane F, Kubisiak TL (1998). Allozyme and RAPD analysis of the genetic diversity and geographic variation in wild populations of the American chestnut. Am J Bot 85: 1013-1021.

Huntley B, Birks HJB (1983). An Atlas of Past and Present Pollen Maps for Europe: 0-13000 year Ago. Cambridge University Press: Cambridge.

International Organization of Palaeobotany (1997). The plant fossil record (PFR v 2.2) database. http://ibs.uel.ac.uk/ palaeo-bin/pfrmap.pl.

Jaynes RA (1975). Chestnut. In: Janick J, Moore J (eds). Advances in Fruit Breeding, Purdue University Press, West Lafayette, IN. pp 490-503.

Johnson GP (1988). Revision of Castanea sect. Balanocastanon (Fagaceae). I Arnold Arboretum 69: 25-49.

Lang P, Huang H (1999). Genetic diversity and geographic variation in natural populations of the endemic Castanea species in China. Bot Sinica 41: 651-657.

Lee NS, Sang T, Crawford DJ, Yeau SH, Kim S-C (1996). Molecular divergence between disjunct taxa in eastern Asia and eastern North America. Am J Bot 83: 1373-1378.

Nei M (1978). Estimation of average heterozygosity and genetic distance from a small number of individuals. Genetics 89: 583-590.

Nei M (1987). Molecular Evolutionary Genetics. Columbia University Press: New York.

Parks CR, Wendel JF (1990). Molecular divergence between Asian and North American species of Liriodendron (Magnoliaceae) with implications for interpretation of fossil floras. Am J Bot 77: 1243-1256.
Pigliucci M, Benedettelli S, Villani F (1991). Spatial patterns of genetic variability in Italian chestnut (Castanea sativa). Can I Bot 68: 1962-1967.

Qiu Y-L, Park CR, Chase MW (1995). Molecular divergence in the eastern Asia - eastern North America disjunct section Rytidospermum of Magnolia (Magnoliaceae). Am J Bot 82: 1589-1598.

Rohlf FJ (2000). Ntsys, Numerical Taxonomy and Multivariate Analysis System. Version 2.1 Exeter Software. Setauket: New York.

Sarich VM (1977). Rates, sample sizes, and the neutrality hypothesis for electrophoresis in evolutionary studies. Nature 265: 24-28.

Sargent CS (1896). Silva of North America 9:10.

Saucier JR (1973). American chestnut... an American wood. USDA Forest Service FS. 230.

Stanford AM (1998). The Biogeography and Phylogeny of Castanea, Fagus, and Juglans based on matK and ITS Sequence Data. PhD Dissertation, UNC, Chapel Hill.

Swofford DL, Selander RB. (1981). BIOSYS-1: a FORTRAN program for the comprehensive analysis of electrophoretic data in population genetics and systematics. J Hered 72: 281283.

Villani F, Pigliucci M, Cherubini M (1994). Evolution of Castanea sativa Mill. in Turkey and Europe. Genet Res 63: 109-116.

Wen J (1999). Evolution of eastern Asian and eastern North American disjunct distributions of flowering plants. Annu Rev Ecol Syst 30: 421-455.

Wolfe JA (1985). Distribution of major vegetational types during the Tertiary. In: Sundquist ET, Broecher WS (eds), The Carbon Cycle and Atmospheric $\mathrm{CO}_{2}$ : Natural Variation Archean to Present, American Geophysical Union, Washington. Vol. 32, pp 357-375.

Zheng Z (1983). The characteristics of the flora and an outline fo the distribution of plants in Hubei province. J Wuhan Bot Res 1, 165-175.

Zhou Z (1999). Fossils of the Fagaceae and their implications in systematics and biogeography. Acta Phytotax Sin 37, 369-385. 